\title{
TRENDS IN LEGUMES ENSILAGING
}

\section{B. Dinić ${ }^{1}$, N. Đorđević ${ }^{2}$, J. Radović ${ }^{1}$, D. Terzić ${ }^{1}$, B. Anđelković ${ }^{1}, M$. Blagojević $^{1}$}

\author{
${ }^{1}$ Institute for Forage Crops Kruševac, 37251 Globoder, Republic of Serbia \\ ${ }^{2}$ Faculty of agriculture, Zemun-Beograd, Nemanjina 6, 11080 Zemun, Republic of Serbia \\ Corresponding author: bora.dinic@ikbks.com \\ Review paper
}

\begin{abstract}
Modern trends in legumes ensilaging technology are based on the knowledge of biomass from the aspect of suitability for ensilaging, wilting, addition of carbohydrate feed, use of biological additives, etc. Today, the experiments are conducted, worldwide, with inoculates, which, in addition to homofermentative, also contain heterofermentative lactic acid bacteria. Products of such inoculants contribute to the increase of aerobic stability of silages so their implementation is good for all types of silage. In addition to the usage of those additions, modern technology of silage is based on the maximum mechanization of the ensilaging process, as well as preparing the silage in the form of roto-bales and silo tubes (most inexpensive way of conservation) as well as permanent facilities.
\end{abstract}

Key words: legumes, silage, carbohydrates, buffer capacity, wilting, carbohydrate feed, inoculants

\section{Introduction}

The general characteristic of livestock nutrition in the lowland and mountain area of Serbia is unfavorable ratio of nutritive substances, or the lack of protein feed. Excess energy in the feed is the result of the presence of maize grain, silage and the corn plant parts. Solution to this problem is to increase the proportion of protein feed in meals. The concentrated protein feed (pellets, oilseed cakes, etc.), are mainly imported and their price is high. A solution to the above problem is to increase proportion of the quality of the bulk food made of the legumes.

Of perennial legumes used for the production of the bulk feed in Serbia, the most important are: alfalfa, red and white clover, bird's-foot trefoil and lupine. Of annual legumes the most important are vetch and forage pea, and less significant are soy, lupine, forage fava beans, etc. 


\section{The importance of legumes for the forage feed production}

High nutritious value of voluminous mass of legumes is underused. The lesser part of total amount of legumes is used as the green mass, while the most part is conserved using different techniques. Conserving of the legumes, as well as other feed, is the inevitable need, primarily because of providing of food during the annual period of vegetation hibernation (Djordjevic and Dinic, 2003). Livestock feed with legumes, in relation to grass feed, provides better utilization of production potential of livestock. Factors that contribute to the superiority of legumes in relation to the grass are: the animals consume larger quantities; decomposition of consumed food and the exploitation of the nutritional substances are more efficient and it contains more specific biological elements (Marten, 1984). One of the most important characteristic of legumes is the ability to use of nitrogen from the atmosphere and the preservation of ecosystems. Alfalfa is the most important forage plant in Serbia. It provides high and stable yield, in the experimental conditions, of $15-20 \mathrm{t}$ of dry matter and about $3.000 \mathrm{~kg}$ of crude protein after the first year (Mejakic et al., 1997). In addition to a high ratio, alfalfa protein contains a large amount of carotene, xantophyll and calcium and is first class of forage feed for all livestock. In favor of this are the studies conducted by Sredojevic et al. (1991), in which carotenoide-protein concentrate are produced from the alfalfa, which in the dry matter contains $57 \%$ of crude protein, crude cellulose $2.10 \%, 10.57 \%$ of crude fat, $35.35 \%$ of essential amino acids, $1052 \mathrm{mg}$ $\mathrm{kg}^{-1}$ of xantophyll and $547 \mathrm{mg} \mathrm{kg}^{-1}$ of $\beta$-carotene.

Red clover is the second important forage culture of the group of perennial legumes. Behind it is white clover, bird's foot trefoil, lupine and others. Quality, as well as in alfalfa, depends on the phase of plant development. Content of crude protein in the dry matter of red clover is $180-200 \mathrm{~g} \mathrm{~kg}^{-1} \mathrm{DM}$, crude cellulose from 210-257 $\mathrm{g} \mathrm{kg}^{-1}$ DM, NFE 430-440 $\mathrm{g} \mathrm{kg}^{-1} \mathrm{DM}$, Ca $13-15 \mathrm{~g} \mathrm{~kg}^{-1} \mathrm{DM}$ and $\mathrm{P} 3.3 \mathrm{~g} \mathrm{~kg}^{-1}$ DM (Dinic et al., 1994a; Djukic et al., 2008).

In terms of the content of nutrient substances for livestock feed, biomass of white clover is one of the highest forage quality. It has the high content of protein and minerals and low content of crude cellulose (Dinic et al., 1994a). It is the one of the forage plants with the most uniform nutritional substances content during the vegetation period, meaning there is the least quality oscillations. The chemical composition of red and white clover and the silage suitability are presented in the Table 1. 
Tabele 1. Chemical composition and buffer capacity of red clover, white clover and maize meal, $\mathrm{g} \mathrm{kg}^{-1} \mathrm{DM}$ (Dinic et al., 1994a)

\begin{tabular}{|l|c|c|c|c|c|}
\hline \multirow{2}{*}{ Parameters } & \multicolumn{2}{|c|}{ Red clover (a1) } & \multicolumn{2}{c|}{ White clover (a2) } & Maize meal \\
\cline { 2 - 6 } & Non wilted & Wilted & Non wilted & Wilted & \\
\hline Dry matter & 204.0 & 320.0 & 161.3 & 281.3 & 870.0 \\
\hline Organic matter & 897.4 & 899.1 & 880.3 & 894.0 & 890.4 \\
\hline Ash & 102.6 & 100.9 & 119.7 & 106.0 & 19.6 \\
\hline Crude proteins & 180.4 & 192.5 & 257.3 & 240.8 & 101.7 \\
\hline Crude fiber & 257.1 & 247.3 & 232.4 & 212.1 & 26.4 \\
\hline Lipids & 21.6 & 28.7 & 31.1 & 26.3 & 48.3 \\
\hline NFE & 438.3 & 430.6 & 359.5 & 411.4 & 804.0 \\
\hline Ca & 14.3 & 12.9 & 13.0 & 12.6 & 0.2 \\
\hline P & 3.2 & 3.3 & 4.2 & 3.9 & 3.4 \\
\hline Sugar (S) & 106 & 124 & 87 & 95 & 44 \\
\hline Buffer capacity (BC) & 60 & 58 & 72 & 50 & 16 \\
\hline S/BC & 1.77 & 2.14 & 1.21 & 1.90 & 2.75 \\
\hline
\end{tabular}

Of perennial legumes in Serbia, mostly forage pea and vetch are used for the production of the bulk animal feed, and rarely or very rarely soy, fava bean and lupine. Annual legumes are very important group of forage crops, because they provide high yield of green mass (30-50 $\mathrm{t} \mathrm{ha}^{-1}$ green mass) of the excellent quality. In the pure crop, protein content was $18-22 \%, 22-26 \%$ of cellulose and $33-40 \%$ NFE in the dry matter (Miskovic, 1986). They can be cultivated in winter, spring or summer sowing, both as a single crop or combined with grain cultures. They, also, fixate nitrogen as the other legumes.

Annual legumes, due to the tendency to lie down, are cultivated the combination with grain crops (oats, rye, wheat, etc.). The quality of biomass, in this case, depends on the proportion of legumes and grain crops. However, in some studies, annual legumes are cultivated in combination with grasses and perennial legumes. In the studies of Latre et al. (2008) there were following combinations: barley + pea, pea + perennial ryegrass + white clover, forage fava beans + spring wheat and pea + alfalfa. When there are favorable conditions or where irrigation is possible, there is a possibility of cultivating of annual legumes and grain crops in summer sowing. Dinic et al. (1999) ensilaged crops of summer sowing: maize + soybean, maize + forage fava beans, sorghum + soybean and sorghum + forage fava beans in different weight ratio, in percents, $(100: 0,75: 25,50: 50,25: 75$ and 0 : 100 ), where the initial material was of the quality presented in Table 2. 
Table 2. Chemical composition of green mass, $\mathrm{g} \mathrm{kg}^{-1} \mathrm{DM}$ (Dinic $\mathrm{i}$ sar., 1999)

\begin{tabular}{|l|c|c|c|c|c|}
\hline Sample & CP & CF & Ash & Ca & P \\
\hline Zea mays & 88.7 & 252.1 & 65.0 & 2.8 & 3.3 \\
\hline Sorghum & 84.4 & 294.6 & 92.9 & 3.6 & 3.4 \\
\hline Soybean & 207.2 & 261.0 & 89.1 & 8.6 & 4.0 \\
\hline Vicia faba & 165.9 & 366.5 & 82.9 & 3.8 & 4.9 \\
\hline LSD 0,05 & 10.23 & 25.66 & 4.69 & 1.00 & 0.71 \\
LSD 0,01 & 15.50 & 38.88 & 7.10 & 1.56 & 1.07 \\
\hline
\end{tabular}

\section{Suitability of legumes for ensilaging}

Biomass conservation, especially the biomass of perennial legumes, is followed by certain losses in dry matter. Due to that, the best is to use the green biomass (pasture). But there is no vegetation in the course of the year, and some legumes have anti-nutritive properties, and can cause certain problems in animal nutrition (bloating, etc.). So, it is necessary to conserve biomass. Hay and silage are the main forms of conserved bulk feed. The hay quality is influenced by weather conditions, so hay is less prepared and used. Its place is taken by silage. Hay is, above all, expensive feed, but the minimum amounts are necessary for normal functioning of the complex digestive system of ruminants. In many countries, there is trend to prepare and use of large amounts of silage compared to hay (Wilkinson and Toivonen, 2003).

Ensilaging is the process of conservation of plant biomass and plant byproducts by lactic acid. Lactic acid is the product of the natural microflora or added (inoculated) selected lactic acid bacteria strains. Suitability of plants for ensilaging can be precisely determined based on the sugar (s) content and on the buffer capacity (BC) (Dinic et al., 1998).

High buffer capacity of legumes (a consequence of the high percentage of protein and minerals - calcium) and small amounts of fermentable carbohydrates are the main limiting factors for the application of silage technology for legumes on the large scale (Dinic et al., 1998). Therefore, since the thirties of the twentieth century, many experiments were performed around the world. The task is to find ways for the successful alfalfa red clover, pea, vetch, soybean, and etc. conservation by ensilaging (Djordjevic and Dinic, 2003). During the development of technology of silage the results of numerous experiments have been successfully used in practice (chemical preservatives based on organic acids, carbohydrate additives, wilting and biological products). Today, in Europe and worldwide, biological products and organic acids are mostly used. The main goal of the modern technologies is the making of silage with higher quality, with the smaller losses of dry matter, the maximum aerobic stability and nutritive value. 


\section{The wilting}

The amount of dry matter in silo mass is one of the most important factors for the level of losses of dry matter and directing the fermentation process in silo mass, especially when it comes to silo mass that is rich in protein and minerals (Dinic, 1990; Dinic et al,. 1997). Wilting, or short-term drying, is certainly the least expensive solution for a successful ensilaging of legumes and mixtures of legumes and grain crops. Effective conservation of wilted crops is explained by ability of lactic acid bacteria to be active in the area with increased osmotic pressure, while most other anaerobic microorganisms can not compete with them. Positive experiences in using this technology are demonstrated experimentally and in local research (Dinic, 1990; Djordjevic, 1995) and are largely applied in practice on our farms (Djordjevic and Dinic, 2003).

There were a lot of studies on the subject of silo mass wilting, but the most complete researches were done under the direction of Zimmer and Wilkins's (1984). The general conclusions of their researches were that there were smaller losses of dry matter in the field in non wilted silo mass $(2.5: 8.6 \%)$, significantly higher in the silo in the silage of non wilted silo mass with preserving agent in relation to the wilted silo mass without preserving agent (16.1:8.5\%). Silages were generally well kept in the two treatments. The preserving agents in silage from non wilted silo mass were based on formic acid, and the wilted silo mass had a $30-40 \%$ of dry matter. Wilting is important due to restraining impact on the level of proteolysis in the legume silages (Djordjevic et al., 2004). However, the possibility of wilting depends on weather conditions, and can not be always done. Also, wilting requires further engagement of mechanization and manpower for the collection of forage mass from the ground, which can easily lead to the contamination with dirt, sand and other substances. Only the biomasses of annual legumes + grain crops in the phase of the beginning of pod formation, with dry matter content about $300 \mathrm{~g} \mathrm{~kg}^{-1}$ can be successfully ensilaged without wilting, or with the direct ensilaging (Dinic et al., 2008).

\section{Mixing with the easily ensilaged crops and the addition of carbohydrate feed}

The mixing with the crops that are easy for the ensilaging is usually done in the early fall, at the time of the last alfalfa cut, as well as silage maize or sorghum from the main or additional sowing (Dinic et al., 1988, 1995). In addition, it is possible to combine alfalfa with grain crops, but in this cases is used mainly the second alfalfa cut (Djordjevic and Dinic, 2003). In such combinations, the 
grain crops provide the required amount of carbohydrates, and legumes enrich ensilaged mass with protein. In the studies by our authors, it is found that the maximum share of alfalfa in the combined silages with maize is 50: 50\% (Dinic et al., 1988). On the practical side, the ratio of maize and alfalfa in the mixture for ensilaging depends first of the available amount of alfalfa.

In order to provide the necessary amount of carbohydrates for lactic fermentation it is practiced to add carbohydrate feed such as ground maize (5$10 \%$ ), molasses (1\%), dry chopped beet (5-10\%) and others (Koljajic et al., 1997).

\section{The use of chemical preserving agents}

The chemical conservation of crops is based on the inhibition of the plant enzymes by reducing the $\mathrm{pH}$ values below 4.5. Today, a small number of chemical preserving agents, mostly organic acids (formic and propionic) and their salts, are being used worldwide. One of the main reasons for this is the aspiration to produce food, both for human and livestock nutrition, as natural as possible, and to obtain the healthier products. In the last decades, in our country, numerous experiments with the use of formic acid were conducted. The effects of formic acid were compared with chemical preservative agents of mineral acids and their salts, carbohydrate additives or bacterial inoculates (Dinic et al., 1994b, 1996, 1997; Djordjevic et al., 2003). Despite very good results, these kinds of additives are not used in our country because of high prices.

\section{The use of biological additives}

The advantage of biological additives in relation to the chemical preserving agents is primarily in that they do not leave residua and do not negatively affect the health of livestock and on the quality of their products. Due to this, they increasingly push out the chemical preserving agents, regardless of their lower efficiency. The experiments conducted in our country confirmed the positive influence of the biological preparations (Djordjevic, 1995; Djordjevic et al., 2000), which are now applied in practice in our large farms (Djordjevic and Dinic, 2003). The greatest effects of bacterial inoculation are expressed in the feed which are difficult to ensilage, especially legumes. By using the homofermentative bacteria cultures the present soluble carbohydrates, which are at the border sugar minimum, are being exploited.

The original products based on lactic acid bacteria contained the homofermentative microorganisms in monoculture or in the combination of several species. The majority of the experiments proved that the combination of different bacteria is more flexible in regard to the choice of the nutritional substances, temperature intervals and other conditions, meaning they complete various aspects 
of their activities, in relation to the monoculture. Modern biological preparations contain Lactobacillus plantarum and other Lactobacillus species, in combination with Enterococcus, Lactococcus and Pediococcus species. In the next phase of development of this technology there is a trend of combining the lactic fermentation bacteria with celulolitic enzymes. By using these products, the intensification achieved of lactic acid fermentation of homofermentative type is achieved. Also, the decomposition of the different fractions of fibers, and at the same time increasing of the content of fermentable carbohydrates, is achieved. Recently, a great attention is paid to the increasing of aerobic stability of silages, especially of maize silages, but, also, of other forage species, due to lactic acid being the main product of fermentation of sugar in the ensilaged mass. The lactic acid has very strong bactericide but weak fungicide properties. In contrast, acetic, byteric and propionic acid have expressed fungicide effects, so the lesser amount of these acids is even desirable in maize silages, as in the other forage species silages, (Table 3).

Table 3. Biochemical changes in alfalfa silages (Avasi et al., 1999)

\begin{tabular}{|l|c|c|c|}
\hline Parameters & Control & Sil-All & Feed Tech \\
\hline PH & 5.12 & $4.75^{\bullet \bullet}$ & $4.82^{\bullet}$ \\
\hline Lactic acid, \% & 1.86 & $2.76^{\bullet \bullet}$ & $2.21^{\bullet}$ \\
\hline Acetic acid, \% & 0.74 & $0.98^{\bullet}$ & $0.81^{\bullet}$ \\
\hline i- butyric acid, \% & 0.015 & 0.015 & 0.0120 \\
\hline n- butyric acid, \% & $0.035^{\bullet}$ & 0.00 & 0.00 \\
\hline Propionic acid, \% & $0.065^{\bullet}$ & 0.015 & 0.015 \\
\hline NH3-N/ $/ \mathrm{N}$, gkg $^{-1}$ & $157.0^{\bullet}$ & 150.2 & 130.7 \\
\hline
\end{tabular}

Sil-All=Streptococcus faecium, Pediococcus acidilactici, Lactobacillus plantarum + enzymes cellulase; Feedtech=Pediococcus acidilactici+Lactobacillus plantarum, $2,5 \times 10^{8}$ cell/g. ${ }^{*} \mathrm{p}<0,05$; $* * \mathrm{p}<0,01$

\section{The significance of modern mechanization for the legumes ensilaging}

One of the modern methods in the technology of feed ensilaging is the preapiring of haylage in bales, wrapped in foils. Currently in the United States, the most economic way of ensilaging is in the form of silo tubes. This does not require the existence of the specialized silo buildings. The prepared bales and silo tubes can be stored under the eaves, or on the field, to the moment of use. Dried plant material that is baled should contain as little moisture as possible, because it is compacted using the press, and it can be further treated with chemicals or inoculates in order to get the better quality. The great advantage of haylage prepared in bales is that it is easy to handle. Due to this, feed that is ensilaged this way is suitable for market (Dinic and Djordjevic, 2005). Results of research 
conducted so far indicate that the equal quality of alfalfa silages is achieved by ensilaging in bales and by ensilaging in the classic silo buildings (Jatkauskas and Vrotniakiene, 2003, Table 4).

Table 4. Chemical composition of silages ensiled by different methods, feed intake and animal performance in the experimental period (Jatkauskas and Vrotniakiene, 2003)

\begin{tabular}{|l|c|c|c|c|}
\hline Parameters & $\begin{array}{c}\text { Silage made in } \\
\text { trench }\end{array}$ & $\begin{array}{c}\text { Silage made in big } \\
\text { bale }\end{array}$ & SEM & $\mathrm{P}$ \\
\hline $\mathrm{pH}$ & 4.52 & 4.65 & 0.1 & $\mathrm{NS}$ \\
\hline Lactic acid & 22.1 & 21.7 & 0.9 & $\mathrm{NS}$ \\
\hline Acetic acid & 17.6 & 14.5 & 1.2 & $\mathrm{NS}$ \\
\hline Butyric acid & 0.01 & 0.00 & 0.0 & $\mathrm{NS}$ \\
\hline $\mathrm{NH}_{3}-\mathrm{N}, \mathrm{g} \mathrm{kg}^{-1} \mathrm{~N}$ & 50.8 & 45.6 & 2.4 & $\mathrm{NS}$ \\
\hline $\mathrm{ME}, \mathrm{MJ} \mathrm{kg}^{-1} \mathrm{DM}$ & 8.89 & 8.94 & 0.9 & $\mathrm{NS}$ \\
\hline $\mathrm{NE}_{\text {intake, MJ day }}{ }^{-1}$ & 88.91 & 98.82 & - & - \\
\hline Silage intake, kg DM & 7.19 & 7.26 & - & - \\
\hline Initial live weight, kg & $356.33 \pm 18.64$ & $354.60 \pm 19.17$ & - & - \\
\hline Total live weight, kg & $159.44 \pm 14.13$ & $163.50 \pm 4.35$ & - & - \\
\hline $\begin{array}{l}\text { Average live weight } \\
\text { gain, kg day }\end{array}$ & $1.115 \pm 0.09$ & $1.143 \pm 0.03$ & - & - \\
\hline
\end{tabular}

\section{Conclusion}

Modern trends in technology of legumes ensilaging are based on the latest scientific and technical achievements. Different procedures are first tested in the experiments, and then introduced into practice. Numerous researches were conducted in our country in accordance with specific conditions, and the acquired knowledge is translated into concrete recommendations, which are largely applied in our practice. Biomasses of both perennial and annual legumes were studied from the aspect of suitability for ensilaging and of the content of water-soluble carbohydrates and buffer capacity. The effect of increasing the content of dry matter (by wilting) on the quality of fermentation and preservation of nutritional substances was, also, studied. Influence of the share of biomass of legumes that are easy to ensile, the impact of share of annual legumes and grain crops on the fermentation quality and nutritive value of silage was studied. The aim of using modern methods of ensilaging is to get the silage of the highest quality from different raw materials, with the optimal satisfaction of a number of nutrient requests, and to produce the maximum healthy products of animal origin for the human use. 


\title{
Trendovi u siliranju leguminoza
}

\author{
B. Dinić, N. Đorđević, J. Radović, D. Terzić, B. Anđelković, M. Blagojević
}

\section{Rezime}

Savremeni trendovi $\mathrm{u}$ tehnologiji siliranja leguminoza zasnivaju se na poznavanju biomasa sa aspekta pogodnosti za siliranje, provenjavanju, dodavanju ugljenohidratnih hraniva, upotrebi bioloških dodataka, i dr. Trenutno se u svetu eksperimentiše sa inokulantima, koji pored homofermentativnih, sadrže i heterofermentativne bakterije mlečne kiseline. Produkti ovakvih inokulanata doprinose povećanju aerobne stabilnosti silaža, pa su navedeni dodaci aktuelni za sve vrste silaža. Osim korišćenja navedenih dodataka, savremena tehnologija siliranja se bazira na maksimalnoj mehanizovanosti celokupnog procesa siliranja, kao i pripremanja silaže $u$ formi roto-bala $i$ silokobasica (najeftiniji vid konzervisanja) kao i stalnih objekata.

\section{References}

AVASI Z., SZÜHCSNE J., MARKY-ZAJNE I.K. (1999): Ensilage of lucerne by biological preservatives. 9. Medzinarodne sympozium "Konzervovanie objemovych krmiv" - Nitra, 6.-8. september 1999. Zbornik referatov, 142-143.

DINIĆ B., STOŠIĆ M., KOLJAJIĆ V. (1988): Uticaj različitog odnosa lucerke i kukuruzne biljke na kvalitet silaže. VI jugoslovenski simpozijum o krmnom bilju. Poljoprivredni institut - Osijek, 22-24.06.1988. Zbornik radova, 525-534.

DINIĆ B. (1990): Uticaj provenjavanja silo-krme crvene deteline i konzervansa na kvalitet silaže. Arhiv za poljoprivredne nauke. 51, 183, 235-244.

DINIĆ B., LUGIĆ, Z., STOŠIĆ, M., RADOVIĆ J. (1994a): Uticaj provenjavanja i nivoa kukuruzne prekrupe na kvalitet silaže crvene i bele dateline. Biotehnologija u stočarstvu, 10, 3-4, 71-80.

DINIĆ B., KOLJAJIĆ V., LAZAREVIĆ D., RADOVIĆ J. (1994b): Effects of cut, dry matter level and formic acid on dynamics of biochemical changes in alfalfa silage. Journal of scientific agricultural research, 198, 56, 77-87.

DINIĆ B., KOLJAJIĆ V., STOŠIĆ M., LAZAREVIĆ D. (1995): Examinations on the possibility of alfalfa ensiling. 7th International symposium Forage conservations. September 18th - 20th, Nitra, Sovak Republic, 105-109.

DINIĆ, B., KOLJAJIĆ, V., STOŠIĆ, M., IGNJATOVIĆ SNEŽANA, LAZAREVIĆ, D. (1996): Korišćenje ugljenohidratnih hraniva i mravlje kiseline za konzervisanje lucerke. VIII jugoslovenski simpozijum o krmnom bilju. Zbornik radova, 26, 491-497. 
DINIĆ B., STOŠIĆ M., NEGOVANOVIĆ D., IGNJATOVIĆ S., TOMIĆ, Z., JEVTIĆ, G. (1997): Influence of plant growth phase, dry mass level and chemical conservators on lucerne ensilage. Proceedings of the 8th International symposium Forage Conservation. Research Institute of Animal Nutrition, Ltd. Pohorelice, 29.09-01.10.1997., 122-123.

DINIĆ, B., KOLJAJIĆ, V., ĐORĐEVIĆ, N., LAZAREVIĆ, D., TERZIĆ, D. (1998): Pogodnost krmnih biljaka za siliranje. Savremena Poljoprivreda, 1-2, 154-162.

DINIĆ B., TERZIĆ D., ĐORĐEVIĆ N., LAZAREVIĆ D. (1999): Effects of individual stubble crops Share on silage quality. $9^{\text {th }}$ International Simposium FORAGE CONSERVATION. $6^{\text {th }}-8^{\text {th }}$ September 2008. Nitra, Slovak Republik, 146-147.

DINIĆ B., ĐORĐEVIĆ N. (2005): Pripremanje i korišćenje silaže (Priručnik). Vizartis - Beograd.

DINIĆ B., ĐORĐEVIĆ N., ĐOKIĆ D., MARKOVIĆ J., ANĐELKOVIĆ S. (2008): Silage quality of companion crops of oat and forage pea. Journal of Mountantian Agriculture on the Bakans, 11, 5, 886-895.

ĐORĐEVIĆ N. (1995): Effects of conserving lucerne with different dry matter content. Review of research work at the faculty of agriculture. 40, 1, 93-107.

ĐORĐEVIĆ N., GRUBIĆ G., ADAMOVIĆ M. (2000): Influence of wilting, inoculant and carbohydrate additives on lucerne silage quality. 51th Annual Meeting of EAAP. The Hague, 21-24 August 2000. Abstract no. 168.

ĐORĐEVIĆ N., DINIĆ B. (2003): Siliranje leguminoza (monografija). Vizartis Beograd.

ĐORĐEVIĆ N., DINIĆ B., GRUBIĆ G., KOLJAJIĆ V. DUJIĆ D. (2004): Kontrola proteolitičkih procesa u siliranoj hrani. X simpozijum o krmnom bilju Srbije i Crne Gore sa međunarodnim učešćem. Acta Agriculturae Serbica. 9, 17, 565-572.

ĐUKIĆ D., STEVOVIĆ V., JANJIĆ V. (2008): Proizvodnja stočne hrane na oranicama i travnjacima. Monografija. Univerzitet u Novom Sadu, Poljoprivredni fakultet, Univertitet u Kragujevcu, Agronomski fakultet u Čačku.

JATKAUSKAS J., VROTNIAKIENE V. (2003): Fermentation characteristic and nutritive value of red clover-grass made in big bales and trench. 11th International symposium "Forage conservation. 9th-11th September 2003, Nitra, Slovak Republic, 90-91.

KOLJAJIĆ V., ĐORĐEVIĆ N., GRUBIĆ G., JOVANOVIĆ R., PAVLIČEVIĆ A., JOKIĆ Ž., DINIĆ B. (1997): Kvalitet silaža spremljenih od leguminoza u zavisnosti od korišćenih postupaka i dodataka. Simpozijum „Naučna dostignuća u stočarstvu '97'. Subotica, 21.-25. april. Zbornik radova, 203-219.

LATRE J., DEWITTE K., WAMBACQ E., DE ROO B., HAESAERT G. (2008): Ensiling of Intercrops with legumes. Procc. $13^{\text {th }}$ International Conference FORAGE CONSERVATION. $3^{\text {rd }}-5^{\text {th }}$ September 2008. Nitra, Slovak Republik, 104-105. 
MARTEN G.C. (1984): Nutritional values of legume in temperate pastures of the U.S. Forage legumes for energy efficient animal production. Proc. Of a Trilateral Workshop Held in Palmerston North, New Zeland, April 30- May 4, 204-213. MEJAKIĆ V., STOJČIĆ J., NEDOVIĆ B., VOJIN S. (1997): Optimalne faze razvoja novostvorene sorte (Medicago sativa L.) "Biljana" za korišćenje. Agroznanje. Nauka - poljoprivreda - iskustvo. Banja Luka, 241-255.

MIŠKOVIĆ B. (1986): Krmno bilje. Naučna knjiga, Beograd.

WILKINSON J.M., TOIVONEN M.I. (2003): World silage-a survey of forage conservation around the world. School of Biology, Universiti of Leeds, Leeds, LS2 9JT, United Kingdom.

ZIMMER E., WILKINS R.J. Efficiencncy of silage systems: a comparision between unwilted and wilted silages. Results of collaborative programe of European Research Institutes 1980-1983. Sonderheft, 69, 5-12. 